\title{
Model of Empowerment of Industrial, Trade, Cooperative and Umkm Services in Murung Raya District
}

Seniwaty", Budi Suryadi, Jamal Uddin

Master Program of Government Science, Lambung Mangkurat University, Banjarmasin, Indonesia

DOI: $10.36348 /$ sjef.2020.v04i06.007 | Received: 30.05 .2020 | Accepted: 08.06.2020 | Published: 12.06 .2020

*Corresponding author: Seniwaty

\section{Abstract}

This study aims to determine and analyze the model of empowerment of Disperindagkop and UMKM of Murung Raya Regency in empowering MSMEs in Murung Raya Regency. A qualitative approach with descriptive methods is used in research. Research informants included the Head of Office, Head of Cooperatives and SMEs, and Head of Section for Disperindagkop and UMKM SMEs in Murung Raya Regency and UMKM Actors in Murung Raya Regency. Data were collected by interview and the results were analyzed using qualitative analysis of Miles and Huberman. Based on the results of the research, the empowerment model implemented by Disperindagkop and MSME Murung Raya Regency is a model that emphasizes a supportive business climate, good financial management, and elements of legality that are fulfilled. Factors that become obstacles in empowerment carried out by Disperindagkop and UMKM Murung Raya Regency include the mindset of MSME actors so that the changes offered through empowerment cannot be implemented quickly. There are limitations to the implementation of empowerment because the empowerment party cannot intervene. The support of resources for empowerment is lacking, because if capital resources can be assisted by the government, then intervention can be done to lead to the better. There are limitations to the implementation of empowerment because the empowerment party cannot intervene. The support of resources for empowerment is lacking, because if capital resources can be assisted by the government, then intervention can be done to lead to the better. There are limitations to the implementation of empowerment because the empowerment party cannot intervene. The support of resources for empowerment is lacking, because if capital resources can be assisted by the government, then intervention can be done to lead to the better.

Keywords: Empowerment, UMKM, and resources.

Copyright @ 2020: This is an open-access article distributed under the terms of the Creative Commons Attribution license which permits unrestricted use, distribution, and reproduction in any medium for non-commercial use (NonCommercial, or CC-BY-NC) provided the original author and source are credited.

\section{Preliminary}

The enactment of Law No. 9 of 2015 mandates that the duties and authorities of some government affairs be delegated to the regions through the decentralization of authority [1]. This is intended to strengthen regional autonomy which also has implications for the opening of development implementation with an approach that is more in line with the characteristics of regional autonomy which requires openness, accountability, and creativity from all state apparatus $[2,3]$.

Increasing the authority of government received by local governments, on one hand, is seen as giving greater space and is a form of empowerment of local governments [4]. On the other hand, it also requires readiness from the local government to accept this authority, as well as the delegation of heavy responsibilities and tasks to the regions, especially the local government bureaucracy in the form of challenges to the implementation of regional governments that are increasingly complex and broad in dimension and will bring significant changes to various fields $[5,6]$.

One thing that is always in the spotlight is related to the economy of the community. One of the potential each region is the existence of Micro, Small, and Medium Enterprises (MSMEs). MSME has a role strategic in labor absorption and sources of regional and local community income. Micro, Small, and Medium Enterprises (MSMEs) in a strategic position to improve people's lives $[7,8]$.

Murung Raya Regency Cooperatives and SMEs to develop Micro and Small and Medium Enterprises where not only MSMEs are on the market, but overall those in Murung Raya Regency are categorized as small and medium industries as illustrated in the following table. 
Table-1: Characteristics of Small and Medium Enterprises in the Murung Raya Regency

\begin{tabular}{|c|c|c|c|}
\hline Indicator & 2013 & 2014 & 2015 \\
\hline Business unit & 189 & 217 & 150 \\
\hline Labor & 353 & 479 & 326 \\
\hline Investment Value (Trillions of Rupiah) & 7,16 & 4.53 & 809,16 \\
\hline Production Value (Trillions of Rupiah) & 18.56 & 13.43 & 142.68 \\
\hline \multicolumn{4}{|c|}{ Top Ten Types of IKM Murung Raya } \\
\hline Industry & Number of Attempts & Total manpower & $\begin{array}{c}\text { Production Value (Million } \\
\text { Rupiah) }\end{array}$ \\
\hline Molding & 21 & 79 & 336 \\
\hline $\begin{array}{l}\text { Maintenance and Repair Data } \\
\text { Motorcycle }\end{array}$ & 7 & 11 & 175 \\
\hline $\begin{array}{l}\text { Rattan and Wicker Crafts } \\
\text { Bamboo }\end{array}$ & 23 & 39 & 76 \\
\hline Red Brick Business & 2 & 6 & 55 \\
\hline Tailor's Clothes & 21 & 31 & 33.6 \\
\hline Woodcraft & 11 & 30 & 22 \\
\hline Brick Printing Business & 1 & 2 & 20 \\
\hline Welding Services & 5 & 13 & 15 \\
\hline Food and Beverage Industry & 17 & 32 & 6.29 \\
\hline
\end{tabular}

Source: Department of Industry, Trade, Cooperatives, and SMEs

Murung Raya Regency, 2016

The data above shows that there was a significant development of investment value and production value in 2015 compared to previous years, but in that year there was also a significant decrease in the number of business units and the number of workers absorbed through MSMEs in Murung Regency Raya This certainly provides that information their positive improvement to MSMEs in Murung Raya Regency even though the involvement of business units and labor has declined. Ideally, business units and labor will also increase over time along with the increase in investment value so that the existence of MSMEs themselves take to effect positive towards providing employment [9].

Regarding this matter, of course, the empowerment model carried out by the Department of Industry, Trade, Cooperatives, and UMKM of Murung Raya Regency must be examined in empowering the existing MSMEs. The role of the Murung Raya Regency Industry, Trade, Cooperatives, and SMEs Office is very closely related to the important role of the government involved in five main forms, namely, first, as a stabilizer, the role of the government stabilizer very important and must be played effectively. Second, as an innovator, the government as a whole must be a source of new things. Third, as a modernizer, the government has to lead Publicis the direction of modern life. Fourth, as a pioneer, the government must be a role model (role model) for the whole community [10]. Fifth, as the executor himself, the government is still required to play a role in implementing various activities [9]. This article aims to describe the empowerment model of the Murung Raya Regency Industry, Trade, Cooperative and UMKM Offices in empowering MSMEs in Murung Raya Regency

\section{RESEARCH METHODS}

The approach that will be used in this research is qualitative because the researcher intends to obtain an in-depth description of the empowerment model of the Department of Industry, Trade, Cooperatives, and UMKM in Murung Raya Regency in empowering MSMEs in Murung Raya Regency. A qualitative approach is a process of research and understanding based on the methodology that investigates a social phenomenon and human problems [11]. In this approach, the researcher makes a complex picture, examines words, detailed reports from the respondents' views, and conducts studies in natural situations. Qualitative methodology is a research procedure that produces descriptive data in the form of written and oral words from people and observed behavior [12].

This research is included in the type of qualitative descriptive research which is intended to study intensively about the background of the problem of the situation and position of an event that is taking place at this time, as well as the specific social unit environmental interactions that are (given) [13]. Research subjects can be individuals, groups, institutions, or society. Descriptive qualitative research is an in-depth study of certain social units and the results of these studies provide a broad and in-depth overview of certain social units. Subjects studied were relatively limited, but the variables and focus under study were very broad in their dimensions [14]. To obtain data and information that is needed for this qualitative research, this required the existence of research informants. The key research informants, namely; 1) Head of Murung Raya Regency Industry, Trade, Cooperative and UMKM Office, 2) Head of Cooperative and UMKM Office of Murung Raya Regency Industry, Trade, Cooperative and SME Office, 
3) Kasi of UKM Development Department of Industry, Trade, Cooperative, and UMKM Murung Raya Regency, and 4) MSMEs in Murung Raya

Regency that will be chosen randomly. Data collection techniques as follows:

1. In-depth interviews to obtain primary data in this study, so that research objectives can be achieved.

2. Observation carried out to deepen the picture obtained through interviews and documentation in this study so that researchers explore themselves in the field of this research.

3. Documentation, recording the form of information either documents or notes, studying books, papers, regulations, research journals and other written materials related to the research topic related to the research problem, but also to support data collection this is with the camera to get data in the form of image visualization.

The technique used in this study is a qualitative analysis technique according to Miles and Huberman, among others; 1) Data reduction, which is the process of selecting, focusing on simplifying the extraction and transformation of raw or rough data that appears in written records in the field. 2) Presentation of data, which is the process of compiling complex information in a systematic form so that it becomes more simple and selective, and its meaning, can be understood. 3) Draw conclusions, namely the analysis is carried out continuously both during and after data collection to draw conclusions that can describe a pattern of events that occur [15]. Researchers can make loose and open conclusions which at first were unclear and then increased to become more detailed and firmly rooted. In maintaining data credibility, it is carried out; 1) Extension of observation, i.e. this study is extended up to three times if the data obtained is deemed inadequate and not credible; 2) Increase perseverance, which is to make observations more closely and continuously so that the certainty of the data and the sequence of events can be recorded with certainty and systematically; 3)Triangulation, that is by crosschecking, that is comparing data obtained from interviews and documentation or by comparing the answers of different informants [16].

\section{RESULTS AND DISCUSSION}

Micro, Small, and Medium Enterprises (MSMEs) are business activities that can expand employment opportunities and provide broad economic services to the community and can play a role in the process of equity and increasing community income, encourage economic growth, and play a role in realizing national stability. Besides, Micro, Small, and Medium Enterprises are one of the main pillars of the national economy that must obtain the main opportunities, support, protection, and development as widely as possible [17] alignments firm to the people's economic business group. Although Micro, Small, and Medium
Enterprises have shown their role in the national economy. But it still faces various obstacles and obstacles, both internal and external, in terms of production and processing, marketing, human resources, design and technology, capital, and business climate. To improve the opportunities, capabilities, and protection of Micro, Small, and Medium Enterprises, various policies regarding business reserves, funding, and development have been set but not yet optimal. That is because the policy has not been able to provide protection, business certainty, and adequate facilities for empowering Micro, Small, and Medium Enterprises [18].

Empowerment is a process of improvement that has been directed ever since by the Regional Government of Murung Raya Regency, especially in economic matters which include micro, small and medium businesses, or better known as MSMEs. The extension of the Murung Raya Regency Government to empower MSMEs is the Department of Industry, Trade, Cooperatives, and MSMEs [19]. Empowerment of MSMEs that are already running, then the support of local governments is to create an empowerment model that leads to further development of MSMEs themselves. The model used in empowering MSMEs in Murung Raya Regency where in the model is the IKUFIL Model (Business Climate, Financial, and Legality). These three things are considered interrelated in empowering MSMEs in Murung Raya Regency. This model is described as a form of empowerment of MSEs in Murung Raya Regency with problems commonly faced by MSME actors themselves in general, in which elements in the model are interconnected and influence each other.

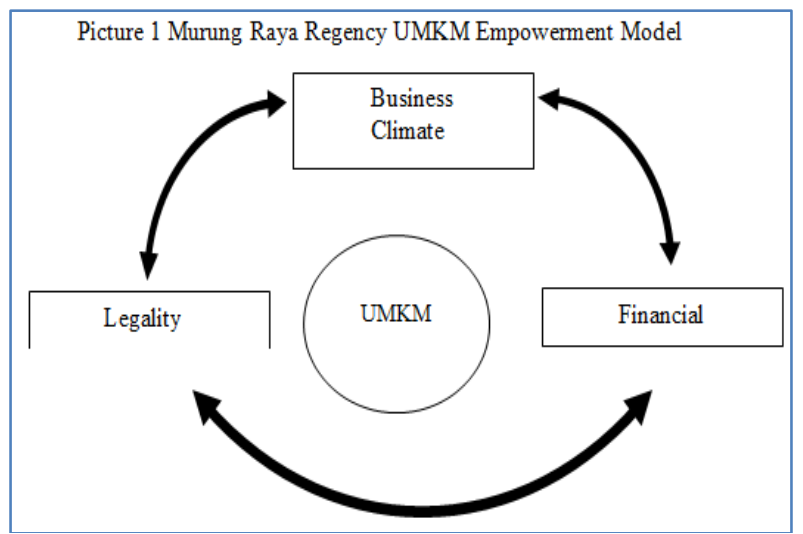

Source: Murung Raya Regency Industry, Trade, Cooperatives, and SMEs Office, 2019

The picture above shows the relationship of elements in the empowerment model used to empower MSMEs in Murung Raya Regency where the elements of the business climate, financial, and legality are important factors in the development of MSMEs in Murung Raya Regency. This empowerment is also internal and external of the SMEs themselves so that the existence of the Murung Raya Regency Industry, Trade, 
Cooperative, and UMKM Offices is important in the process. Empowerment directs people to be aware of their abilities and to utilize existing strengths to be empowered and can be utilized for activity which means. Empowerment in this type is related to everything related to human activities themselves, where the necessities of life must be met by those concerned independently. Therefore, in the empowerment of MSMEs, in general, can be interpreted as an effort to restore or improve the ability of a community to be able to do under their dignity and dignity in carrying out their rights and its responsibilities as members of the community in the MSME business they run.

The existence of empowerment is expected by the community to have a proactive culture for mutual progress, to know themselves and their environment, and to have a responsible attitude and position themselves as subjects in development efforts in their environment. The empowerment approach taken is the emphasis on the importance of independent local communities as a system that organizes themselves. Such a community empowerment approach is certainly expected to give a role to individuals, not as the object, but as actors or actors who determine their own lives. Rubin in Sumaryadi (2005: 94-96) put forward 5 basic principles of the concept of community empowerment as follows:

1. Community empowerment requires a break-even in every activity it manages, although the orientation is different from business organizations, wherein community empowerment the benefits obtained are redistributed in the form of programs or other development activities. In the empowerment model made by the Department of Industry, Trade, Cooperatives, and UMKM Murung Raya Regency, it can be seen that there is a break-even though it is descriptive, not quantitative, for example, there is a target of the number of MSME changes from traditional financial management to through adequate recording good.

2. Community empowerment always involves community participation in both planning and implementation.

3. In implementing this empowerment model, community participation is needed because they are the main actors in the MSME business. Therefore this model was formed based on problems faced by SMEs in the field for which information was collected through a process the workshop early so that the model can be arranged empowerment with training methods related to the problems faced by the SMEs.

4. In carrying out community empowerment programs, training activities are elements that cannot be separated from physical development efforts.

5. The empowerment model implemented by the Murung Raya Regency Industry, Trade,
Cooperatives, and SMEs Office takes the form of a training program where in addition to physical development in the form of a market, training is also carried out one related to the existing empowerment model. An example is the gradual training of MSME players for good financial management so that MSMEs can also develop and are also bankable for better access to capital or also for greater business development. Therefore, on that occasion also the SMEs who are considered stable and able to develop businesses are directed to increase the stock of goods so that greater business operational transactions, or directed to invest in adding new branches or directed to buy a fleet that helps business operations which of course capital structure can be directed to the banks.

6. In its implementation, empowerment efforts can maximize resources, especially in terms of financing both from the government, private sector, and other sources. In the application of the Murung Raya Regency Department of Industry, Trade, Cooperatives, and SMEs, the available resources for capital financing are more independent of capital and also the capital structure of banks. The local government is considering assisting in the form of training and the workshop to develop their business. This is considered where MSMEs with their capital have a sense of belonging big on the business they run, so that if the capital provided by the government will cause a lack of ownership of the MSMEs whose capital is from the government, besides that the risk for these funds will not return too large because the new MSMEs whose capital structure has not been tested from the government have not yet been tested. It would be different if the independent capital structure would certainly be carried out with full responsibility for the capital owner.

7. Community empowerment activities must be able to function as a link between macro government interests and community interests that are micro. The existing empowerment model contributes to the development of a stable and growing MSME community, this is a macro help for the government by helping to reduce the unemployment rate and improve the overall economyPublicwhich exists. Micro community interests can also be fulfilled by the availability of wider employment opportunities, and Murung Raya Regency is an alternative to efforts to improve the people's standard of living due to falling commodity prices rubber which has been a mainstay of the people of Murung Raya Regency as their income.

Concerning inhibiting factors in the empowerment of MSMEs in Murung Raya

Regency by the Department of Industry, Trade, Cooperatives and MSMEs of Murung Raya Regency, it is necessary to look at the factors that influence community empowerment, which Sumaryadi (2005: 
154-158) outlines into eight influential factors as following:

1. The willingness of a community to receive the empowerment. Obstacles related to this have become very pronounced in the application of the empowerment model of the Department of Industry, Trade, Cooperatives, and SMEs of Murung Raya Regency. Empowerment in the form of training is not directly accepted by SMEs.

2. Perception of empowerment and empowerment. The perception of empowerment and empowered deserves attention, because this also applies to the empowerment model implemented by the Department of Industry, Trade, Cooperatives, and SMEs of Murung Raya Regency.negative.

3. Culture, people are patterned in thinking and doing in routine. The existing empowerment model cannot be applied as a whole at one time in the hope of change toward positive fast.

4. There is no relinquishment of authority to be handed over to the community. Related to this obstacle did not occur, the authority over the existing empowerment model only applies to the Department of Industry, Trade, Cooperatives, and UMKM of Murung Raya Regency, without intervention so that its authority is fully surrendered to the community of SMEs through the training and follow-up workshops.

5. Empowerment limit; UMKM assistance conducted by the Department of Industry, Trade, Cooperatives, and UMKM Murung Raya Regency also cannot intervene because the capital structure is also independent so that MSME actors who are also owners of capital pay very close attention to measures that can be assessed out of the ordinary.

6. Community trust; Regarding public trust in the concept, it is not an obstacle, but the belief in making changes is an obstacle due to risk considerations because they think "the hot ball is in their hands". However, this has been realized by the Murung Raya Regency Industry, Trade, Cooperative and UMKM Office, so that in the next stage of the workshop and training there is always an inspiring session for MSME entrepreneurs to carry out their business in the manner conveyed by the Industry, Trade Office, Cooperative and UMKM Murung Raya Regency and this has a positive effect on the trust of the community of MSME actors to the Department of Industry, Trade, Cooperatives and UMKM of Murung Raya Regency.

7. Empowerment is not conducive to rapid change; Indicator of changes in access to banking, the commencement better financial records for fulfillment from banks began to be realized and so as associated with licensing, where this happens gradually over a fairly long period because of the pattern think from the community of SMEs themselves.

8. Support of resources (resource); Changes expected through the application of the empowerment model delivered through training and workshops by the Murung Raya Regency Industry, Trade, Cooperatives, and SMEs Office are recognized in the field as obstacles due to lack of available resources. For example, directives for simple financial accounting are not easy to digest and can be applied quickly because of the limitations on the support of human resources, in addition to developing the business more broadly through structure capital can also be constrained by capital resources, although not very significant.

\section{CONCLUSION}

The empowerment model implemented by the Murung Raya Regency Industry, Trade, Cooperatives, and SMEs Office is a model that emphasizes a supportive business climate, good financial management, and the elements of legality that are fulfilled. Factors which become obstacles in empowerment carried out by the Department of Industry, Trade, Cooperatives and SMEs of Murung Raya Regency include; 1) The mindset of MSME actors so that the changes offered through empowerment cannot be carried out quickly, 2) There are limitations to implementing empowerment because the empowerment party cannot intervene, and 3) The support of resources for empowerment is lacking, because if resources capital can be helped from the government, so intervention can be done to lead to the better.

Ideally, the Murung Raya Regency Department of Industry, Trade, Cooperatives, and SMEs needs to make a long-term quantitative target related to the existing empowerment model to be more measurable in achieving the results of implementing the empowerment model. For example, in 6 months, the number of MSMEs that had licenses was 30\%, and those that had access to banking capital were $75 \%$, so it was clearer what was being pursued. However, for the Murung Raya Regency Industry, Trade, Cooperative and UMKM Offices also need to create MSME groups (with a capital structure from the local government) that can be intervened to show that what is directed by the Murung Raya Regency Industry, Trade, Cooperatives and UMKM Offices can have a positive impact on MSME businesses,

\section{REFFERENCE}

1. Nyoman, I. S. (2005). Perencanaan Pembangunan Daerah Otonom dan Pemberdayaan Masyarakat. Jakarta: Citra Utama.

2. Khoiruddin. (1992). Pembangunan Masyarakat: Tinjauan Aspek Sosiologi, Ekonomi, dan Perencanaan. Yogyakarta: Liberty.

3. Widjaja, H. (2003). Otonomi Desa. Jakarta: PT Raja Grafindo Persada.

4. Huraerah, A. (2008). Pengorganisasian \& Pengembangan Masyarakat. Bandung: Humaniora. 
5. Hikmat, H. (2010). Strategi Pemberdayaan Masyarakat. Bandung: Humaniora Utama Press.

6. Aziz, M. A. (2005). Dakwah Pemberdayaan Masyarakat: Paradigma Aksi Metodologi. Yogyakarta: PT. LKiS Pelangi Nusantara.

7. Resalawati, A. (2011). Pengaruh Perkembangan Usaha Kecil Menengah Terhadap Pertumbuhan Ekonomi Pada Sektor UKM Indonesia. E-journal Universitas Islam Negeri Syarif Hidayatullah.

8. Partomo, T. S., \& Soejoedono, A. R. (2004). Ekonomi Skala Kecil/Menengah dan Koperasi. Jakarta: Ghalia Indonesia.

9. Siagian, P. S. (2008). Pengantar Manajemen. Jakarta: Bumi Aksara.

10. Suharto, E. (2005). Membangun Masyarakat Memberdayakan Rakyat. Bandung: PT. Refika Aditama.

11. Afifudin, dan Saebani, B. A. (2012). Metodologi Penelitian Kualitatif. Bandung : Pustaka Setia.

12. Moleong, L. J. (2002). Metode Penelitian Kualitatif. Bandung: PT Remaja Rosdakarya.
13. Bungin, B. (2008). Metode Penelitian Kualitatif. Aktualisasi Metodologi ke. Arah ragam Varian Kontemporer. Jakarta: Rajawali Press.

14. Yusuf, A. M. (2017). Metodologi Penelitian Kuantitatif, Kualitatif \& Penelitian Gabungan. Jakarta: Prenada Media Group.

15. Nasution. (2009). Metode Research (Penelitian Ilmiah). Jakarta: Bumi Aksara.

16. Creswell, J. W. (2010). Research Design Pendekatan Kualitatif, Kuantitatif, dan. Mixed. Yogyakarta: Pustaka Pelajar.

17. Adi, I. R. (2013). Kesejahteraan sosial (Pekerjaan sosial, Pembangunan Sosial, dan Kajian Pembangunan). Jakarta: PT. Raja Grafindo Persada.

18. Tulus, T. (2012). Usaha Mikro Kecil dan Menengah di Indonesia: Isu-Isu Penting. Jakarta: LP3ES.

19. Sumodiningrat, G. (1999). Pemberdayaan Masyarakat dan Jaringan Pengaman Sosial. Jakarta: PT Gramedia Pustaka Utama. 